\title{
Purification of the Extracellular Opacity Factor of a Strain of Group A Streptococcus M Type 2
}

\author{
By O. V. MARTINEZ,* D. F. RIPPE, $\dagger$ L. FULLER \\ AND M. M. STREITFELD \\ Department of Microbiology, University of Miami School of \\ Medicine, Miami, Florida 33152, U.S.A.
}

(Received 15 February 1977; revised 26 October 1977)

The extracellular Opacity Factor elaborated by a strain of group A streptococcus $M$ type 2 was purified by ammonium sulphate precipitation, DEAE-cellulose and hydroxylapatite column chromatography and Sephadex G-200 gel filtration. Gel filtration experiments indicated that the Opacity Factor is constituted of high molecular weight proteins or protein aggregates which appear to dissociate into subunits of 66000 minimum molecular weight as determined by sodium dodecyl sulphate-polyacrylamide gel electrophoresis. The purified preparations had no group A carbohydrate or T protein antigens. Passive haemagglutination and indirect immunofluorescence tests indicated that Opacity Factor is distinct from the $M$ type 2 protein antigen.

\section{INTRODUCTION}

Certain serotypes of group A streptococci possess the ability to produce opalescence in human or animal sera. This serum opacity reaction (SOR) is mediated by a factor (OF) which acts upon the $\alpha_{1}$-lipoprotein fraction of serum (Krumwiede, 1954).

The OF is type-specific and its specificity parallels the $\mathrm{M}$ antigen of the particular $\mathrm{SOR}^{+}$ strain, but not the $T$ or $R$ protein antigens of the same strain. Several investigators have studied the relationship between the OF and these other streptococcal surface antigens. Gooder (1961) demonstrated an inverse relationship between type-specific $M$ antigens and OF in particular strains. In contrast, Top \& Wannamaker $(1968 b)$ showed a consistent association between several $M$ serotypes and the exhibition of the SOR. More recent studies by Widdowson et al. (1971) have indicated that cell-bound OF is closely related to the $M$ antigens of $\mathrm{SOR}^{+}$strains. They were unable to separate the two entities in cellular extracts from two $\mathrm{SOR}^{+}$strains by biochemical procedures and suggested that the $\mathrm{OF}$ and $\mathrm{M}$ antigens may form a part of the same protein molecules. Other studies by Cleary, Johnson \& Wannamaker (1975) on the phenotypic instability of the $M$ antigen in relation to $O F$ in $\mathrm{SOR}^{+}$serotypes led these investigators to conclude that the $\mathrm{M}$ and $\mathrm{OF}$ antigens were distinct, although their synthesis might be directly or indirectly controlled by a single gene or linked genes which segregated as a unit.

In this study we have attempted to clarify further the relationship between the $M$ and OF antigens by making OF preparations free from other cell-associated components. To date, most information on the nature of the OF has emerged from studies of cellular extracts containing $\mathrm{M}$ protein and $\mathrm{OF}$ from $\mathrm{SOR}^{+}$streptococci. Some of these extraction procedures

* Present address: Department of Surgery, University of Miami School of Medicine, Miami, Florida 33152, U.S.A.

$\dagger$ Present address: Dade Division of American Hospital Supply Corp., Miami, Florida, U.S.A. 
yielded impure preparations (Phillips \& Pine, 1971) while, at the same time, the structure of the extracted M and OF antigens may have been altered (Lange, Lee \& Merdinger, 1969; Widdowson, Maxted \& Grant, 1970; Widdowson et al., 1971). To avoid these problems in extracting cell-bound OF our efforts were directed at extracellular SOR-active materials.

\section{METHODS}

Organisms. Streptococcus $\mathrm{M}$ type 2 (SOR ${ }^{+}$) strain $\mathrm{T} 2 / 44 / \mathrm{RB} 4 / 119$ was obtained from Dr R. C. Lancefield of the Rockefeller University, New York, U.S.A.; M type 57 (SOR ${ }^{-}$) strain 71-724 and $\mathrm{M}$ type 49 (SOR $\left.{ }^{+}\right)$ strain 71-716 were from Dr L. W. Wannamaker of the University of Minnesota, U.S.A. Cultures were routinely propagated on Difco Todd-Hewitt $(\mathrm{TH})$ agar plates containing $5 \%(\mathrm{v} / \mathrm{v})$ sheep blood (THB). Cultures were stored at $-60{ }^{\circ} \mathrm{C}$ in $\mathrm{TH}$ broth containing $20 \%(\mathrm{v} / \mathrm{v})$ glycerol.

Antisera. Antisera against group A streptococci T types 2 (lot no. R1486/3), 8 (lot no. RL3/2), 25 (lot no. R1219/6) and IMP19 (lot no. R4/4) were from Dr W. R. Maxted of the Public Health Laboratories, Colindale, London. Absorbed $M$ type 2 (lot no. 8) and $M$ type 57 (lot no. 1) specific antisera were from Ds R. Facklam of the Center for Disease Control, Atlanta, Georgia, U.S.A.

Antiserum against the purified OF prepared in our laboratory was obtained after immunization of adult New Zealand rabbits with material from the SOR-active protein peak (pI $4 \cdot 3$ ) recovered from an isoelectric focusing column, $\mathrm{pH}$ range 4 to 6 . The purified $\mathrm{OF}\left(0.97 \mathrm{mg}\right.$ protein $\left.\mathrm{ml}^{-1}\right)$ was mixed with an equal volume of Freund's complete adjuvant (Difco). Each rabbit was given a $1 \mathrm{ml}$ injection of this preparation underneath each scapula. These immunizations were followed by similar injections after a rest period of 3 weeks. Additional booster immunizations were administered as before, except that Freund's incomplete adjuvant (Difco) was used.

Streptococcus group A carbohydrate antiserum was obtained from Difco (lot no. 605984).

Horse serum. Serum (lot nos E051511 and A531403) was obtained from Grand Island Biological Company, New York, U.S.A.

Determination of SOR activity. SOR activity was measured by a modification of the method of Top \& Wannamaker $(1968 a)$. Each sample $(0.2 \mathrm{ml})$ of the test material was placed in a screw-capped test-tube $(9.5 \times 1.5 \mathrm{~cm})$ and mixed with $1 \mathrm{ml}$ horse serum and one drop of $1 \%(\mathrm{w} / \mathrm{v})$ merthiolate. The tubes were incubated at $37{ }^{\circ} \mathrm{C}$ for $18 \mathrm{~h}$, and the absorbance of the mixture was measured at $475 \mathrm{~nm}$ in a Gilford 2000 spectrophotometer. Control mixtures contained $0.2 \mathrm{ml}$ saline instead of the test sample. Values of absorbance taken before incubation were subtracted from the final readings. SOR activity was measured by diluting the test samples in saline solution to give absorbance values between 0.2 and 0.9 . Previous experiments had shown that within this range there is a linear relationship between OF concentrations and the development of serum opalescence. Total SOR activity ( $\mathrm{OFu}$ ) was calculated as the product of $A_{475}$, the dilution factor and the total volume of the sample. Specific activity was derived from the quotient of the total SOR activity and the protein concentration of the sample.

Measurement of SOR inhibition by rabbit immune sera. Portions $(0.2 \mathrm{ml})$ of the OF test preparations were placed in screw-capped test-tubes and mixed with equal volumes of rabbit immune serum. The mixtures were incubated at $37^{\circ} \mathrm{C}$ for $1 \mathrm{~h}$, kept at $4{ }^{\circ} \mathrm{C}$ overnight and then centrifuged. The supernatant fluids were decanted into screw-capped test-tubes and assayed for residual SOR activity. Pre-immunization rabbit serum and saline solution were used as controls.

Lancefield extracts. SOR-active materials were solubilized from whole cells by the method of Lancefield \& Perlmann (1952) for extracting M proteins.

Column chromatography. Whatman DE52 anion-exchange cellulose (DEAE-cellulose) was equilibrated with $0.1 \mathrm{M}$-potassium phosphate buffer pH 7.5 containing $0.1 \mathrm{M}-\mathrm{NaCl}$ [all buffers contained $0.02 \%(\mathrm{w} / \mathrm{v})$ sodium azide]. The sample to be chromatographed was dialysed overnight $\left(4^{\circ} \mathrm{C}\right)$ against the same buffer, adjusted to $20 \mathrm{mg}$ protein ( $\mathrm{ml}$ packed cellulose $)^{-1}$ and then carefully layered on top of the cellulose bed. The column was washed with the starting buffer until no protein could be detected in the washings. The column was eluted with a linear salt gradient from $0.1 \mathrm{M}$ to $0.6 \mathrm{M}-\mathrm{NaCl}$ in $0.01 \mathrm{M}$-potassium phosphate buffer $\mathrm{pH} 7 \cdot 5$. All chromatography was performed at $25^{\circ} \mathrm{C}$. A flow rate of 95 to $100 \mathrm{ml} \mathrm{h}^{-1}$ was maintained and $6 \mathrm{ml}$ fractions were collected.

Bio-gel hydroxylapatite (HTP) (Bio-Rad) was rehydrated in 0.05 M-potassium phosphate pH 6.8 and the slurry was packed into a $2.5 \times 25 \mathrm{~cm}$ column. The sample to be chromatographed $[2 \mathrm{mg}$ protein $(\mathrm{ml}$ bed volume $)^{-1}$ ] was dialysed overnight against the same buffer, then applied as described before. The column was eluted with a linear gradient of increasing phosphate $(\mathrm{pH} \mathrm{6.8)}$ concentration from $0.05 \mathrm{M}$ to $0.4 \mathrm{M}$-potassium phosphate. The flow rate was $95 \mathrm{ml} \mathrm{h}^{-1}$ and $6 \mathrm{ml}$ fractions were collected.

Sephadex G-200 (Pharmacia) was rehydrated in $0.02 \mathrm{M}$-potassium phosphate buffer $\mathrm{pH} 7.5$ and the gel was packed into a $2.5 \times 36 \mathrm{~cm}$ column. The sample to be chromatographed was concentrated approximately 
10-fold in an Amicon Ultrafiltration unit with a pM10 Amicon Diaflo membrane at a maximum nitrogen pressure of $40 \mathrm{lbf}$ in $^{-2}(280 \mathrm{kPa})$. A sample of the concentrated material $(1.6 \mathrm{ml}$ containing $1.92 \mathrm{mg}$ protein $\mathrm{ml}^{-1}$ ) was layered on top of the gel and the column was eluted with $130 \mathrm{ml}$ of the starting buffer at $9 \mathrm{ml} \mathrm{h}^{-1}$; $3 \mathrm{ml}$ fractions were collected.

Sepharose $6 \mathrm{~B}$ was packed into a $2.5 \times 43 \mathrm{~cm}$ column and a sample $(1.2 \mathrm{ml})$ of the HTP fraction $(1.92 \mathrm{mg}$ protein $\mathrm{ml}^{-1}$ ) was layered on top. The column was eluted with $150 \mathrm{ml} 0.02 \mathrm{M}$-potassium phosphate buffer pH 7.5 at $20 \mathrm{ml} \mathrm{h}^{-1}$ and $3.7 \mathrm{ml}$ fractions were collected.

Isoelectric focusing. This was performed in an LKB 8101 electrofocusing column with $2 \%(\mathrm{w} / \mathrm{v})$ LKB carrier ampholytes, $\mathrm{pH}$ range 3 to 10 . The preparation to be electrofocused was dialysed against $0.01 \mathrm{M}$-Tris/ $\mathrm{HCl}$ buffer $\mathrm{pH} 7.0$ for $24 \mathrm{~h}$ before application to the column. Samples of $5 \mathrm{ml}\left(0.97 \mathrm{mg}\right.$ protein $\left.\mathrm{ml}^{-1}\right)$ were introduced in the middle fractions of a sucrose density gradient as a substitute for the less dense solution. Each sample was electrofocused for 24 to $36 \mathrm{~h}$ at $4{ }^{\circ} \mathrm{C}$. The column was then evacuated by means of a peristaltic pump $\left(2 \mathrm{ml} \mathrm{min}^{-1}\right)$ and $2 \cdot 1 \mathrm{ml}$ fractions were collected.

Disc gel electrophoresis. This followed the method of Davis (1964), using a final acrylamide concentration of $5 \%(\mathrm{w} / \mathrm{v})$. Electrophoresis was performed at $25^{\circ} \mathrm{C}$ at an initial current of $1 \mathrm{~mA}$ per gel for 15 to $20 \mathrm{~min}$, followed by an increase to $4 \mathrm{~mA}$ per gel for the duration of the experiment. For some experiments, $8 \mathrm{M}$-urea was added to the sample as well as to the separating and stacking gels.

Disc gel electrophoresis in the presence of sodium dodecyl sulphate (SDS) was done as described by Talbot \& Yphants (1971), except that $7 \%$ acrylamide gels were used. The $0.2 \mathrm{M}$-Tris/acetate pH 8.2 buffer system contained $0.2 \%$ (w/v) SDS. A $0.4 \mathrm{ml}$ sample of the test preparation (1 mg protein $\mathrm{ml}^{-1}$ ) was mixed with $0.05 \mathrm{ml}$ buffer, $0.05 \mathrm{ml} 10 \%$ (w/v) SDS in distilled water and $5 \mu \mathrm{l}$ 2-mercaptoethanol. Each mixture was boiled in a water bath for $5 \mathrm{~min}$, allowed to cool in a loosely capped test-tube and then a $40 \mu \mathrm{l}$ sample was layered on to each gel. Electrophoresis was done as before, except that the final current was $5 \mathrm{~mA}$ per gel. The staining solution was $0.05 \%(\mathrm{w} / \mathrm{v})$ Coomassie blue in $12.5 \%(\mathrm{w} / \mathrm{v})$ trichloroacetic acid.

Passive haemagglutination test. A variation of the method of Stavitsky \& Arquilla (1958) was used. In order to coat tanned sheep erythrocytes with a highly purified OF preparation, $1 \mathrm{ml}$ of $0.5 \%$ erythrocyte suspension was centrifuged and the packed cells were resuspended in an equal volume of a Sephadexpurified OF preparation containing $0.76 \mathrm{mg}$ protein $\mathrm{ml}^{-1}$; the mixture was then incubated at $37^{\circ} \mathrm{C}$ for $30 \mathrm{~min}$. The coated cells were centrifuged, washed once in 2 vol. phosphate-buffered saline (PBS) pH 7.2 containing $0 \cdot 1 \%(\mathrm{w} / \mathrm{v})$ gelatin and resuspended to the original volume in the same buffer. Twofold dilutions of normal and immune rabbit sera (heat inactivated at $56^{\circ} \mathrm{C}$ for $1 \mathrm{~h}$ ) were made in a microtitre plate (Cooke Engineering Co.) containing $0.05 \mathrm{ml}$ buffer in each well. The same volume of coated cells was added to each well. Tanned, uncoated erythrocytes and coated cells without serum were used as controls.

Indirect fluorescent staining. Sheep erythrocytes were tanned and coated with a Sephadex-purified OF preparation as described above. Samples $(0.05 \%)$ were placed in $100 \times 12 \mathrm{~mm}$ glass test-tubes and centrifuged at $600 \mathrm{~g}$ for $10 \mathrm{~min}$. Each cell pellet was resuspended in $0.2 \mathrm{ml}$ of normal (control) or immune rabbit serum and incubated at room temperature for $1 \mathrm{~h}$. The cells were recentrifuged, washed once in PBS and resuspended in $0.3 \mathrm{ml}$ fluorescein-conjugated goat anti-rabbit IgG (Miles Laboratories, Elkhart, Indiana, U.S.A.). After $30 \mathrm{~min}$ incubation at $25^{\circ} \mathrm{C}$, the cells were again washed as described before and resuspended in the minimum volume of the same buffer. Each preparation was wet-mounted on a $75 \times 25 \mathrm{~mm}$ glass slide and examined in a Leitz microscope equipped with a Ploem incident light illuminator, an HBO $\mathrm{Hg}$ lamp and a combination of KP490 exciting and K495 suppressor flters.

Capillary precipitin test. The method used was that recommended by the Center for Disease Control for the typing of group A $\beta$-haemolytic streptococci (CDC Laboratory Division, Scientific Resources Branch, Biological Reagents Section, Atlanta, Georgia, U.S.A., October, 1969).

Analysis by immunodiffusion was performed as described by Kieffer \& Halbert (1976).

Protein determination. The formula of Warburg \& Christian (1964) was used to evaluate ultraviolet light-absorption determinations at 280 and $260 \mathrm{~nm}$.

Total carbohydrate determination. The phenol-sulphuric acid procedure described by Dubois et al. (1956) was used.

\section{RESULTS}

The supernatants from 36 to $48 \mathrm{~h}$ streptococcal TH broth cultures grown at $37{ }^{\circ} \mathrm{C}$ were filtered through a Millipore membrane filter $(0.45 \mu \mathrm{m}$ pore size) and subsequently treated as shown in Fig. 1.

\section{Ammonium sulphate fractionation}

To the culture filtrates at $4{ }^{\circ} \mathrm{C}$, crystalline ammonium sulphate was added to achieve the desired saturation levels according to the formula of Dixon (1953). Precipitates were collected 


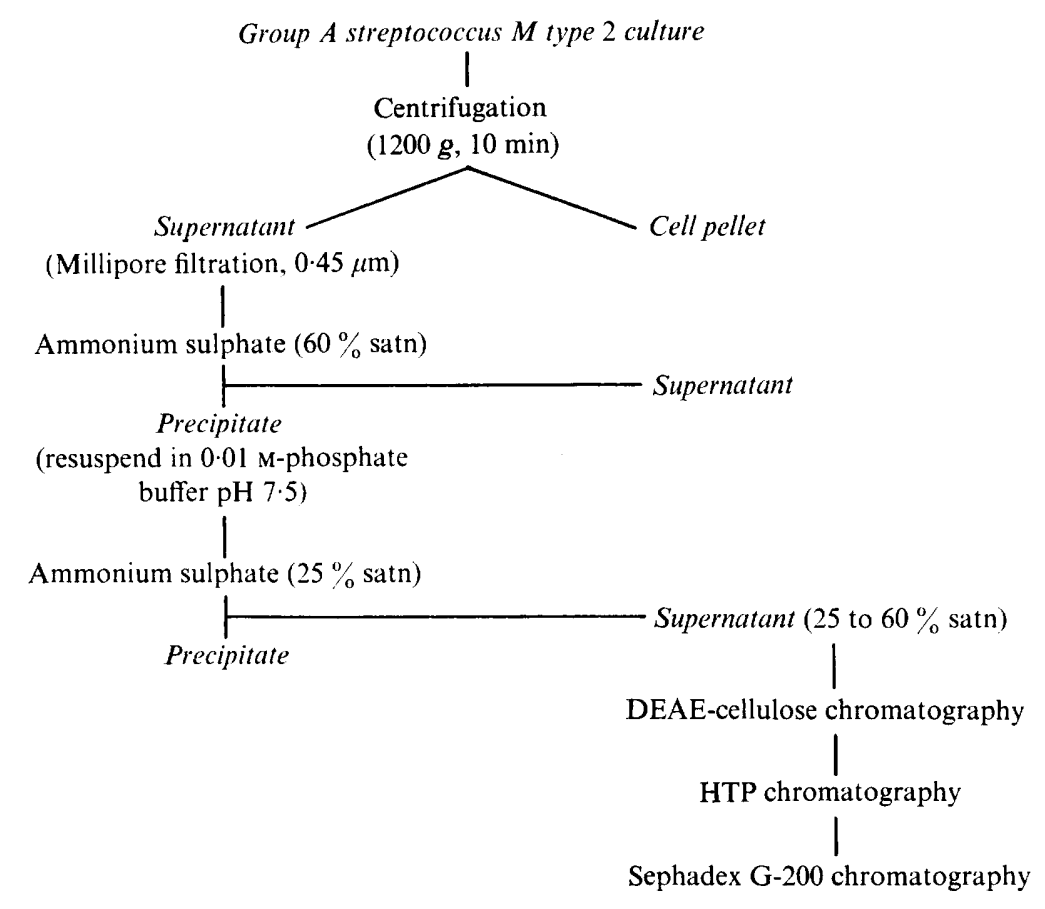

Fig. 1. Procedure for purifying the OF in culture supernatants of an M type 2 streptococcus, strain T2/44/RB4/119.

Table 1. Yield and purity at different stages in the purification of oF from $M$ type 2 streptococci strain $\mathrm{T} 2 / 44 / \mathrm{RB} 4 / 119$

\begin{tabular}{|c|c|c|c|c|c|c|}
\hline Sample & $\begin{array}{l}\text { Volume } \\
\text { (ml) }\end{array}$ & $\frac{A_{280}}{A_{260}}$ & $\begin{array}{c}\text { Protein } \\
\left(\mathrm{mg} \mathrm{ml}^{-1}\right)\end{array}$ & $\begin{array}{l}\text { Total } \\
\text { protein } \\
(\mathrm{mg})\end{array}$ & $\begin{array}{l}\text { Total } \\
\text { activity } \\
(\mathrm{OFu})\end{array}$ & $\begin{array}{c}\text { Specific } \\
\text { activity } \\
{[\text { OFu }} \\
\left.(\mathrm{mg} \text { protein })^{-1}\right]\end{array}$ \\
\hline $\begin{array}{l}\text { Culture } \\
\text { filtrate }\end{array}$ & 3000 & 0.71 & $9 \cdot 61$ & 28830 & 16830 & 0.58 \\
\hline $\begin{array}{l}25 \text { to } 60 \%\left(\mathrm{NH}_{4}\right)_{2} \mathrm{SO}_{4} \\
\text { precipitate }\end{array}$ & 156 & 1.00 & 6.05 & 943.8 & 13150 & 13.93 \\
\hline $\begin{array}{l}\text { DEAE-purified } \\
\text { fraction }\end{array}$ & 106 & 1.00 & $2 \cdot 03$ & $215 \cdot 2$ & 10804 & $50 \cdot 20$ \\
\hline $\begin{array}{l}\text { HTP-purified } \\
\text { fraction }\end{array}$ & 16 & $1 \cdot 01$ & $3 \cdot 29$ & $52 \cdot 6$ & 10530 & $200 \cdot 19$ \\
\hline $\begin{array}{l}\text { Sephadex G-200- } \\
\text { purified fraction }\end{array}$ & 202 & $1 \cdot 16$ & 0.08 & $16 \cdot 2$ & 7239 & $446 \cdot 85$ \\
\hline
\end{tabular}

by centrifugation $(10400 \mathrm{~g}, 15 \mathrm{~min})$, resuspended in $0.01 \mathrm{M}$-potassium phosphate buffer $\mathrm{pH} 7.5$ and dialysed for $48 \mathrm{~h}$ against the same buffer. A single precipitation at $80 \%$ saturation was sufficient to precipitate almost all of the SOR-active materials in the culture fluids. However, serial precipitations at 20,40,60 and $80 \%$ saturation showed that most of the SOR activity could be recovered in the 40 to $60 \%$ saturation fraction. Lower levels of activity were found in the 20 to $40 \%$ saturation fraction but no activity was detected in the $20 \%$ and 60 to $80 \%$ saturation fractions. In similar experiments using different saturation levels, we found that up to $94 \%$ of the SOR activity in the initial filtrate could be recovered by precipitation between the 25 and $60 \%$ saturation levels. This procedure was therefore adopted for the initial isolation of extracellular SOR-active materials (Table 1). 


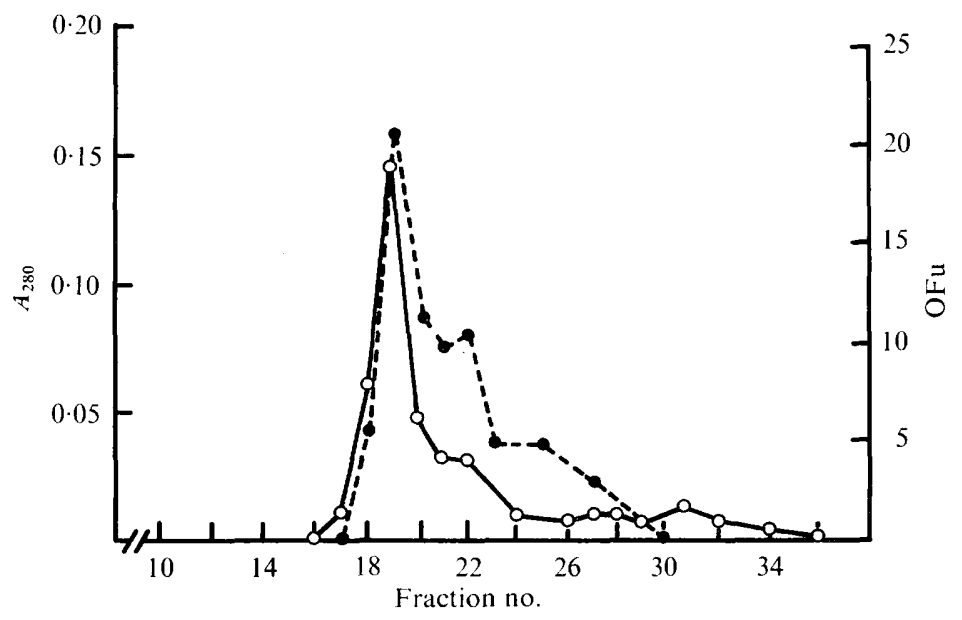

Fig. 2. Sepharose 6B chromatography of the SOR-active fraction obtained by hydroxylapatite column chromatography. The void volume of the column was $66 \mathrm{ml}$ (fraction no. 18). $\bigcirc$, relative protein concentration $\left(A_{280}\right) ; \boldsymbol{\bullet}$, SOR activity $(\mathrm{OFu})$.

\section{DEAE-cellulose chromatography}

The 25 to $60 \%$ saturated $\left(\mathrm{NH}_{4}\right)_{2} \mathrm{SO}_{4}$ fraction was further separated by chromatography on DE52 columns. The material eluted from the column throughout the initial washings with the starting buffer had no SOR activity and contained most of the brown-coloured material in the $\left(\mathrm{NH}_{4}\right)_{2} \mathrm{SO}_{4}$ fraction. With increasing ionic strength in the $\mathrm{NaCl}$ gradient, most of the proteins remaining in the column were eluted in a large protein peak which trailed throughout the final fractions collected. Examination of individual eluate fractions indicated that maximum SOR activity coincided with maximum protein concentration.

\section{HTP chromatography}

The DE52-purified material was further fractionated by HTP column chromatography. As before, all samples collected during the initial washings were SOR-negative. The SOR activity profile again resembled that of the eluted protein with all the activity concentrated in a broad peak, although this peak was not coincident with the main protein peak. The carbohydrate content of the HTP-purified samples was small. In a representative experiment, $16 \mu \mathrm{g}$ carbohydrate $\mathrm{ml}^{-1}$ was detected in the pooled SOR-active fractions containing $0.85 \mathrm{mg}$ protein $\mathrm{ml}^{-1}$.

\section{Sephadex G-200 and Sepharose 6B chromatography}

The HTP-purified SOR-active fractions were further fractionated by gel filtration procedures. A SOR-active protein peak was detected in the fractions corresponding to, and immediately following the void volume of a Sephadex G-200 column. All other fractions contained small amounts of protein but no detectable SOR activity. Because the apparently high molecular weight of the SOR-active materials equalled or exceeded the exclusion limits of Sephadex G-200, the HTP-purified materials were examined by gel filtration with Sepharose 6B. Most of the SOR activity was again detected near the void volume of the column (fraction no. 18; Fig. 2). However, SOR activity was not confined to the peak but was spread throughout numerous fractions. The presence of SOR activity near the void volume of the column suggests that the $\mathrm{OF}$ is composed of proteins, or protein aggregates of very high molecular weight $(>800000)$. 


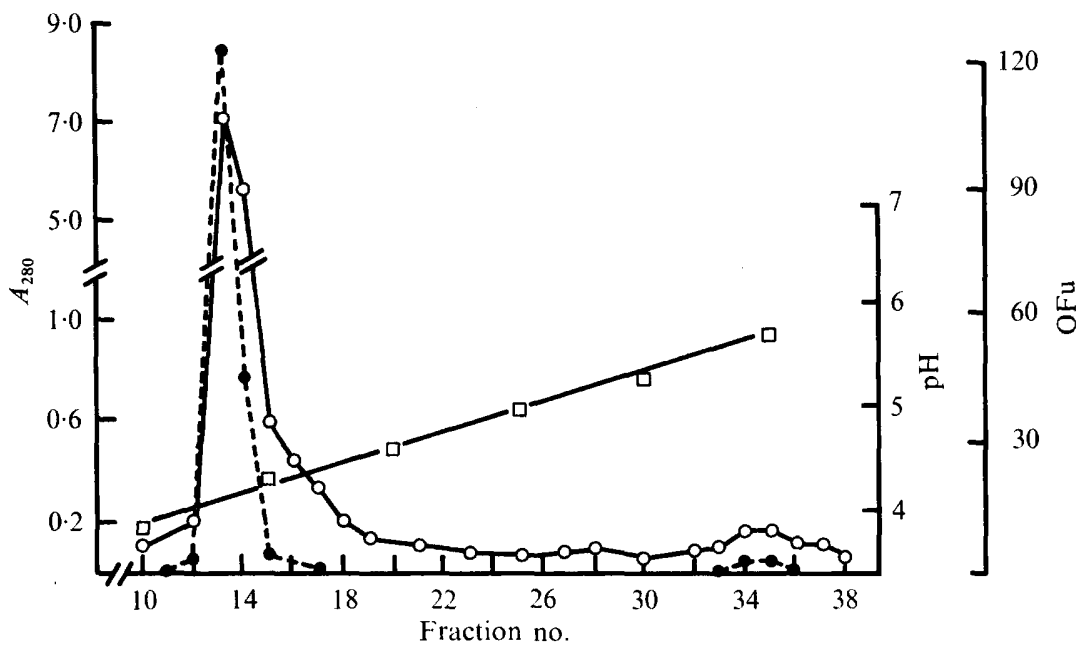

Fig. 3. Isoelectric focusing (pH range 4 to 6 ) of the SOR-active fraction from Sephadex G-200 fractionation. $\bigcirc$, Relative protein concentration $\left(A_{280}\right) ; \bullet$, SOR activity $(\mathrm{OFu}) ; \square, \mathrm{pH}$.

\section{Isoelectric focusing}

Since Sepharose 6B fractionation was less satisfactory than the preceding method with Sephadex, products of the latter were taken for further characterization by isoelectric focusing. Initially, a wide $\mathrm{pH}$ range of 3 to 10 was selected. Most of the proteins together with the SOR activity were concentrated in a single band near the anode at an average isoelectric point (pI) of 4.8. All other fractions were devoid of SOR activity or significant amounts of protein. Similar experiments were made with LKB carrier ampholytes using a $\mathrm{pH}$ range of 4 to 6 . This was done as described before except that a $7.2 \mathrm{ml}$ sample $(1.8 \mathrm{mg}$ protein $\mathrm{ml}^{-1}$ ) was applied to the column. Again, most of the SOR-active material was concentrated in a single protein peak ( $\mathrm{pI} 4 \cdot 3$ ) while a much smaller peak containing traces of SOR activity was observed near the terminal fractions of the column (pI 5.7) (Fig. 3). The amount of material from this second peak was too small for further characterization.

\section{Disc gel electrophoresis}

Analysis of OF preparations (purified by Sephadex chromatography and isoelectric focusing) by $5 \%$ polyacrylamide gel electrophoresis showed that most of the proteins remained within the stacking gel and the interphase between the stacking and separating gels. In addition, two faint protein bands were often observed towards the middle of the gels, but not when relatively small amounts of proteins $(<80 \mu \mathrm{g})$ were used. No SOR activity was detected within the gels by incubating $0.3 \mathrm{~cm}$ thick gel slices in tubes containing horse serum. When gel slices were held at $37^{\circ} \mathrm{C}$ for $3 \mathrm{~h}$ followed by overnight refrigeration at $4{ }^{\circ} \mathrm{C}$, the supernatant fiuids still lacked SOR activity.

When the same materials were examined by disc gel electrophoresis in $8 \mathrm{M}$-urea, a single strongly stained protein band was observed (Fig. 4). In addition, small amounts of diffuse, lightly stained materials were found near the position of the tracking dye. These bands were not assayed for SOR activity; separate experiments have indicated that $8 \mathrm{M}$-urea prevents the development of SOR.

\section{Molecular weight determinations}

On SDS-polyacrylamide disc gel electrophoresis, the SOR-active fractions obtained from Sephadex G-200 and isoelectric focusing columns of pH range 4 to 6 produced a single, strongly stained protein band for which a molecular weight of 66000 was calculated. 


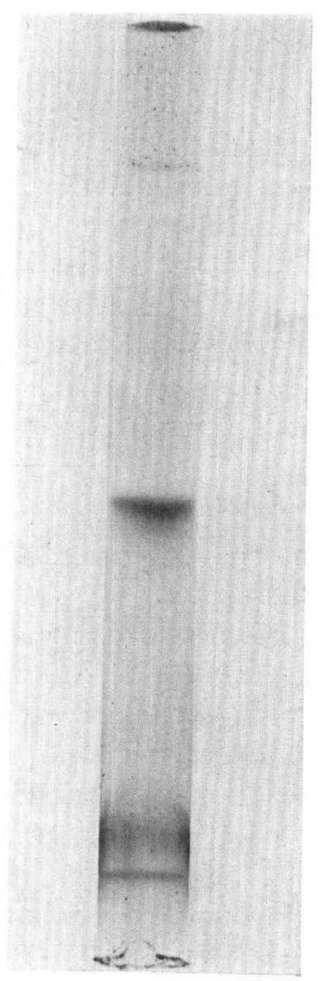

Fig. ${ }^{5} 4$

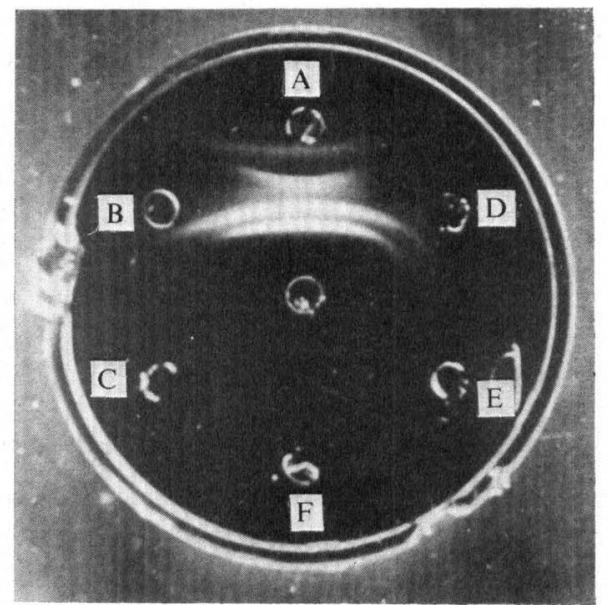

Fig. 5

Fig. 4. Polyacrylamide gel electrophoresis of the SOR-active fraction obtained from an isoelectric focusing column $\mathrm{pH}$ range 4 to 6 . Both the separating and stacking gels contained $8 \mathrm{M}$-urea. The gel was stained with $0.05 \%(\mathrm{w} / \mathrm{v})$ Coomassie blue in $12.5 \%(\mathrm{w} / \mathrm{v})$ trichloroacetic acid.

Fig. 5. Double diffusion agar test. $M$ type 2 specific antiserum (centre well) was tested against Lancefield extracts from $M$ type 2 streptococci strain T2/44/RB4/119 (A), M type 49 strain 71-716 (B) and $M$ type 57 strain 71-724 (C), and against the following extracellular OF preparations from $M$ type 2 organisms strain T2/44/RB4/119: saturated ammonium sulphate ( 25 to $60 \%$ )-purified OF (D), HTP-purified OF (E) and Sephadex G-200-purified OF (F).

\section{Development of antisera against $O F$}

Antisera against OF preparations purified by isoelectric focusing were difficult to produce. The animals responded only after extensive immunization with adjuvant, and their immune sera were only weakly reactive when tested by double diffusion in agar against either cellextracted or extracellular OF preparations. Precipitation reactions in immunodiffusion tests were often accompanied by diffuse, opaque areas which were difficult to distinguish from faint precipitation lines. This generalized opacity was interpreted as being due to SOR since similar areas of opalescence were observed with various normal rabbit, human, horse or rat sera. Both in immunodiffusion and capillary precipitin tests, OF antiserum reacted with extracellular preparations at all stages of purification and, less strongly, with Lancefield SOR-active M-protein extracts from the immunizing strain. No reaction was observed with hot-acid cellular extracts or $60 \%\left(\mathrm{NH}_{4}\right)_{2} \mathrm{SO}_{4}$ precipitate fractions from the culture fluids of $\mathrm{M}$ type 57 (SOR ${ }^{-}$) organisms.

The specificity of the antisera for the OF in the highly purified preparations was demonstrated by immune SOR-inhibition experiments. For example, incubating Sephadex purified materials with OF antiserum almost completely abolished their SOR activity. The final $A_{475}$ values of these mixtures represented levels of opalescence which are only faintly visible to the naked eye $(0 \cdot 240)$. In contrast, strong opalescence occurred in SOR-active 
preparations incubated either with pre-immunization rabbit sera $\left(A_{475}=1.0\right)$ or with physiological saline $\left(A_{475}=0 \cdot 610\right)$. Samples incubated with control, normal rabbit serum produced higher levels of opalescence than did those incubated with saline. This is because rabbit serum acts as a substrate for OF, thus contributing to the subsequent development of opalescence during incubation at $37^{\circ} \mathrm{C}$. Even so, the levels of residual SOR activity in mixtures with OF immune serum were considerably lower than those in mixtures with physiological saline.

Only partial SOR inhibition was observed in similar experiments where OF antiserum was incubated with Lancefield cellular extracts from the immunizing strain. As previously suggested by Widdowson et al. (1970), this may be attributed to the partial denaturation of the OF as a result of the harsh conditions of the Lancefield extraction procedure.

\section{Immunological characterization of highly purified OF preparations}

The extracellular OF preparations and Lancefield cellular extracts from $M$ type 2 organisms were tested by immunodiffusion and capillary precipitin tests against antisera specific for a number of streptococcal surface antigens. Group A carbohydrate antiserum reacted only with Lancefield cellular extracts of the test strains. Antisera against $T$ protein antigens 2, 8, 25 and IMP19, usually associated with M type 2 strains (Maxted \& Widdowson, 1972), failed to react with cellular extracts and extracellular OF preparations. In contrast, $\mathrm{M}$ type 2 specific antisera produced not only strong precipitin reactions with the Lancefield cellular extracts but also weaker reactions with $60 \%$ saturated $\left(\mathrm{NH}_{4}\right)_{2} \mathrm{SO}_{4}$ precipitates from culture supernatant fluids of our test $M$ type 2 strain.

Similar results were obtained in double diffusion agar tests (Fig. 5). M type 2 antiserum reacted neither with SOR-active preparations obtained from Sephadex G-200 or isoelectric focusing columns nor with Lancefield cellular extracts from $\mathrm{M}$ serotypes 57 (SOR ${ }^{-}$) and $49\left(\mathrm{SOR}^{+}\right)$.

Passive haemagglutination tests were performed in an attempt to detect very low levels of antibodies reactive against our purified OF preparations in our $M$ type 2 specific antisera. Again, both this antiserum and pre-immunization rabbit sera failed to produce a positive reaction whereas $\mathrm{OF}$ antiserum produced a haemagglutination titre of $1: 512$.

These results were further substantiated by indirect immunofluorescence tests where intense fluorescence was observed on the surface of OF-coated erythrocytes exposed to OF antiserum. No fluorescence was observed on cells incubated with $M$ type 2 or normal rabbit sera, nor in control preparations where the fluorescein-conjugated immunoglobulins had been reacted with tanned, coated erythrocytes not previously exposed to any rabbit sera.

Despite the failure of $M$ type 2 specific antisera to react with the highly purified extracellular OF preparations, SOR inhibition tests indicated a partial inhibition of the opalescence produced by Sephadex-purified OF preparations. In parallel experiments with the same antiserum and Lancefield cellular extracts from the same bacterial strain, SOR inhibition was at a minimum, when at all detectable.

\section{DISCUSSION}

Our procedures for the isolation and purification of OF were designed to obtain maximum yields of the SOR-active materials in culture supernatants of the test strain.

Carboxymethylcellulose chromatography at an acid $\mathrm{pH}$ had been used for the partial purification of $M$ type antigens 1 and 12 (Fox \& Wittner, 1965; Strauss, Metha \& Lange, 1974) and the $M$ and OF antigens in Lancefield extracts of $M$ types 2 and 49 streptococci (Widdowson et al., 1971). In our experiments, however, the ammonium sulphate-purified SOR-active test samples partially precipitated when dialysed against phosphate buffers at the slightly acidic $\mathrm{pH}$ of $5 \cdot 5$. We therefore used DEAE-cellulose chromatography at a slightly alkaline $\mathrm{pH}(7 \cdot 5)$ for the initial fractionation of the crude OF material. The sequen- 
tial use of DEAE-cellulose, hydroxylapatite and Sephadex G-200 fractionation produced a purer OF preparation than has been reported to date.

Widdowson et al. (1971) showed that the OF and $M$ antigens in Lancefield extracts of $M$ type 2 and 49 streptococci could be detected in the high molecular weight fractions recovered from the void volume of Sephadex G-100 and G-200 columns. Our similar gel filtration experiments indicated that the OF found in the culture supernatant fluids of our test strain was also of high molecular weight. This was confirmed by disc gel electrophoresis since most of the proteins present in these highly purified samples did not migrate towards the anode in $5 \%$ acrylamide gels. The fact that almost all of the proteins migrated as a single band in gels containing $8 \mathrm{M}$-urea suggests they may be uncontaminated but we were unable to recover SOR activity from the gels. Conclusive evidence must await identification of the protein bands within the polyacrylamide gels. The examination of the highly purified SOR-active materials by disc gel electrophoresis in the presence of SDS yielded a single protein band. This may represent the minimum polypeptide subunit in the structure of the OF. If so, OF is composed of identically sized repeating subunits.

The OF appeared to be electronegative and homogeneous in net electrical charge as indicated by the detection, in isoelectric focusing columns, of almost all of the SOR-active materials as a single protein band (pI 4.3). It is of interest to compare this result with that reported for $M$ proteins where a higher $\mathrm{pI}$ of 5.5 has been observed (Fox, 1974). These observations thus indicate a significant difference in the molecular structures of the $M$ and OF antigens. Although the physical and chemical nature of the former is incompletely understood, most investigators now agree that the $\mathbf{M}$ antigens are composed of multiple molecular structures (Fox, 1974). Our studies indicate that although M antigen and OF materials are both present in culture supernatant fluids and in Lancefield extracts from whole cells, they are not identical, nor does the OF appear to be related to the surface $T$ protein antigens or to the group carbohydrate.

It was difficult to prepare antiserum against our highly purified OF preparations. The low levels of serum antibody response of rabbits immunized with these preparations may be ascribed to weak immunogenicity of the OF. Earlier findings by Widdowson et al. (1970) have indicated that the OF in some strains of streptococci is indeed poorly antigenic. The $M$ type 2 antiserum was, however, able to inhibit SOR. While this property suggests that the type-specific antiserum contains antibodies specific for the OF in highly purified extracellular preparations, the lack of reactivity of the same antiserum with these preparations by the various sensitive immunological procedures makes it difficult to interpret. An analogous observation was made by Widdowson et al. (1971). They reported the preparation of antisera that neutralized the SOR activity of the immunizing strain but had little or no $M$ precipitin activity. Conversely, many potent anti-M sera exhibited no SOR inhibitory activity.

\section{REFERENCES}

Cleary, P., Johnson, Z. \& Wannamaker, L. (1975). Genetic instability of the $M$ protein: evidence suggesting extrachromosomal control. Infection and Immunity 12, 109-118.

DAvis, B. J. (1954). Disc electrophoresis. II. Methods and application to human serum proteins. Annals of the New York Academy of Science 121, 404-427.

Dixon, M. (1953). A nomogram for ammonium sulphate solutions. Biochemical Journal 54, 457458 .

Dubois, M., Gilles, K. A., Hamilton, J. K., Rebers, P. A. \& SMith, F. (1956). Colorimetric method for determination of sugars and related substances. Analytical Chemistry 28, 350-356.
Fox, E. N. (1974). M proteins of group A streptococci. Bacteriological Reviews 38, 57-81.

Fox, E. N. \& WitTner, M. K. (1965). The multiple molecular structure of the $\mathbf{M}$ proteins of group A streptococci. Proceedings of the National Academy of Sciences of the United States of America 54, $1118-1125$.

GOODER, H. (1961). Association of a Serum Opacity Reaction with serological type in Streptococcus pyogenes. Journal of General Microbiology 25, $347-352$.

Kieffer, D. \& Halbert, S. P. (1976). Purification of group C streptococcal extracellular antigens detected with naturally occurring human anti- 
bodies. Isolation of streptokinase and two previously undescribed antigens. Infection and Immunity 13, 501-512.

KrUMwiEdE, E. (1954). Studies on a lipoproteinase of group A streptococci. Journal of Experimental Medicine 100, 629-638.

Lancefield, R. C. \& Perlmann, G. E. (1952). Preparation and properties of type-specific $M$ antigen isolated from group A type 1 hemolytic streptococcus. Journal of Experimental Medicine 96, 71-82.

Lange, C. F., Lee, R. \& Merdinger, E. (1969). Chemistry and end-group analysis of purified $\mathbf{M}$ proteins of type 12 group A streptococcal cell walls. Journal of Bacteriology 100, 1277-1283.

MAXTED, W. R. \& Widdowson, J. P. (1972). Streptococci and Streptococcal Diseases, pp. 252266. Edited by L. W. Wannamaker and J. M. Matsen. New York: Academic Press.

Phillips, L. S. \& Pine, L. (1971). Evaluation of methods used to purify acid-extracted group A streptococcal M protein. Applied Microbiolsgy 22, 963-973.

Stavitsky, A. B. \& Arquilla, E. R. (1958). Studies of proteins and antibodies by specific hemagglutination and hemolysis of proteinconjugated erythrocytes. International Archives of Allergy 13, 1-38.

Strauss, D. C., Metha, A. \& Lange, C. F. (1974). Simplified method for the purification of group A streptococcal $M$ proteins. Solution of the multiple binding problem. Applied Microbiology 27, 28-37.

Talbot, D. N. \& Yphants, D. A. (1971). Fluorescent monitoring of SDS disc gel electrophoresis. Analytical Biochemistry 44, 246-256.

Top, F. H. \& WANnAmaker, L. W. (1968a). The Serum Opacity Reaction of Streptococcus pyogenes: the demonstration of multiple, strainspecific lipoproteinase antigens. Journal of Experimental Medicine 127, 1013-1034.

Top, F. H. \& Wannamaker, L. W. $(1968 b)$. The Serum Opacity Reaction of Streptococcus pyogenes: frequency of production of streptococcal lipoproteinase by strains of different serological types and the relationship to $\mathbf{M}$ protein production. Journal of Hygiene 66, 49-58.

WarburG, O. \& Christian, W. (1964). Cited in Manometric Techniques, 4th edn. Edited by W. W. Umbreit, R. H. Burris \& J. F. Staufer. Minneapolis: Burgess Publishing Company.

Widdowson, J. P., MAXTEd, W. R. \& Grant, D. L. (1970). The production of opacity in serum by group A streptococci and its relationship with the presence of $\mathrm{M}$ antigen. Journal of General Microbiology 61, 343-353.

Widdowson, J. P., Maxted, W. R., Grant, D. L. \& PinNeY, M. M. (1971). The relationship between $\mathrm{M}$-antigen and Opacity Factor in group A streptococci. Journal of General Microbiology 65, 69-80. 